\title{
Experimental models of 'Basement'-controlled salients - application to the Proterozoic fold-thrust belt of the Quadrilátero Ferrífero (Minas Gerais, Southeastern Brazil)
}

\author{
CAROLINE J. S. GOMES, MILTON PEREIRA-FILHO and SILVIA C. M. BRAGA
}

Universidade Federal de Ouro Preto, Departamento de Geologia, 35400-000 Ouro Preto, MG, Brasil

Manuscript received on August 19, 2002; accepted for publication on March 7, 2003; presented by BENJAMIN B.B. NEVES

\begin{abstract}
Scaled sandbox models are used to simulate the development of 'basement'-controlled, salients. We investigate the controlling factors on the development of closed curvatures in map-view, considering constant both the sand pack thickness and the space between obstacles. These models are compared with the FundãoCambotas Fault System in the Proterozoic fold-thrust belt in the Quadrilátero Ferrífero region, along the southeastern margin of the São Francisco craton. In the experiments, a pronounced curvature resulted from the margin-controlled salient process in the presence (i) of a basal ductile detachment, or (ii) of pre-existing structures. The results suggest that the convex-to-the-foreland, west-vergent Fundão-Cambotas Fault System that borders the Archean basement highs and displaced older Transamazonian structures westward, is partly a consequence of interaction of propagating thrusts with obstacles in the foreland.
\end{abstract}

Key words: experimental modelling, salients, brittle deformation, ductile deformation, Quadrilátero Ferrífero.

\section{INTRODUCTION}

Research related to the origin of mountain belt curvature was initiated by the classical work of Carey (1955) who defined 'oroclines' as curved mountain belts that developed curvature because of the bending of an initially straight orogen. Based on a bibliographical compilation of the map-view geometry of 20 fold-thrust belt salients and on physical and numerical models, Macedo (1997) described six types of salients or curvatures convex-to-theforeland, which may form when a thrust fault system propagates 1) in an irregular basin (involving along-strike basin depth variation); 2) ahead of an indenter (a rigid crustal block in the hinterland); 3 )

Correspondence to: Caroline J.S. Gomes

E-mail: caroline@degeo.ufop.br along an irregular continental margin with prominent pre-existing basement highs in the foreland; 4) over a basal detachment with lateral variations of rheology; 5) with the interaction of late transcurrent faults at a high angle to the tectonic transport direction and 6) reflecting the geometry of a subducting plate.

In this study, analogue sandbox experiments were carried out to analyze the Fundão-Cambotas Fault System curvature, in the Quadrilátero Ferrífero, in map-view (Fig. 1). Based on the current tectonic models (Alkmim and Marshak 1998) this salient is related to the third type of curvature in the above classification, i.e., the margin- or 'basement'controlled salients. We simulate the margincontrolled curvature model and discuss the factors 
that could have influenced formation of the parabolic curvature of the eastern Quadrilátero Ferrífero foldthrust belt. Specifically, we examined the role of different basal-detachment rheology when the fold thrust-belt is molded onto an irregularly shaped margin, and the significance of a structural high, the Serra do Caraça structural high of the Quadrilátero Ferrífero supracrustal sequence, in the hinterland (Fig. 1).

Our experiments demonstrate that a high parabolic curvature similar to that of the FundãoCambotas Fault System is not likely to have formed only in consequence of two lateral 'basement' obstacles. Other factors, such as pre-existing structures in the subsurface, a horizontal layer providing a zone of weakness along which a ductile detachment occurred or a third obstacle that progressively assumed the role of a backstop moving between structural highs, should have influenced the deformation history.

\section{THE QUADRILÁTERO FERRÍFERO}

The Quadrilátero Ferrífero is located in the southern portion of the Archean and Paleoproterozoic São Francisco craton, in southeastern Brazil. A Neoproterozoic fold-thrust belt of the Brasiliano orogeny borders the entire eastern margin of the São Francisco craton and involves the eastern part of the Quadrilátero Ferrífero (Fig. 1). In this area, the fold-thrust belt is composed of two major thrust fault systems: the Fundão-Cambotas Fault System in the foreland and the Água Quente Fault System in the hinterland. The map-view of the Fundão-Cambotas Fault System defines a salient (i.e., a convex to the foreland curve). Based on field work and on geometrical and kinematic criteria, these thrusts were interpreted to be linked thrust faults limited laterally by oblique ramps (e.g. Dorr 1969, Endo and Fonseca 1992). Alkmim and Marshak (1998) suggested that the arcuate trace of the Fundão-Cambotas Fault System resulted from the westward propagation of thrust sheets confined between basement highs composed of pre-existing Archean metamorphic complexes, the Caetés Metamorphic Com- plex to the north and the Bação Metamorphic Complex/Rio das Velhas Arch to the south. These basement highs would have acted as obstacles, inhibiting thrust propagation at both extremes of the curvature.

The nearly north-south Água Quente Fault System is composed of a stack of west-vergent imbricate structures. At the eastern side of the Serra do Caraça structural high, Ribeiro-Rodrigues (1992) described high-angle reverse thrust faults wrapping around the quartzite high. According to the author, these thrust faults connect at depth to a basal detachment which emerges to the west, where it is known as the Caraça Fault (Fig. 1).

\section{EXPERIMENTAL PROCEDURES}

Six analogue modeling experiments were conducted in a glass-sided deformation box with internal dimensions of $30 \times 36.5 \times 5 \mathrm{~cm}$ (width $\times$ length $\times$ height). The movement of the frontal wall, generated by the action of a coupled motor, allowed a progressive deformation of the analogue material arranged in horizontal layers under a constant displacement rate of $2 \mathrm{~cm} / \mathrm{h}$ to maximum displacement of $11 \mathrm{~cm}$. All experiments were repeated several times to test reproducibility.

Each experiment was photographed from above at a time interval of once an hour. At the end of the experiments the sand was wetted and vertical sections parallel to the tectonic transport direction were cut and photographed. The models contained two rigid obstacles in the foreland representing two basement highs, the Caetés Metamorphic Complex and the Bação Metamorphic Complex/Rio das Velhas Arch, and a rigid indenter in the hinterland, representing the Serra do Caraça structural high (Fig. 1), as the main boundaries.

No specific shortening values, based on profile restorations, are available for the Quadrilátero Ferrífero. Therefore, we tested a range of different shortening values and observed that the increase in deformation magnitude does not significantly modify the curvature geometry in the sand models. The maximum shortening we used in our models was $30 \%$. 


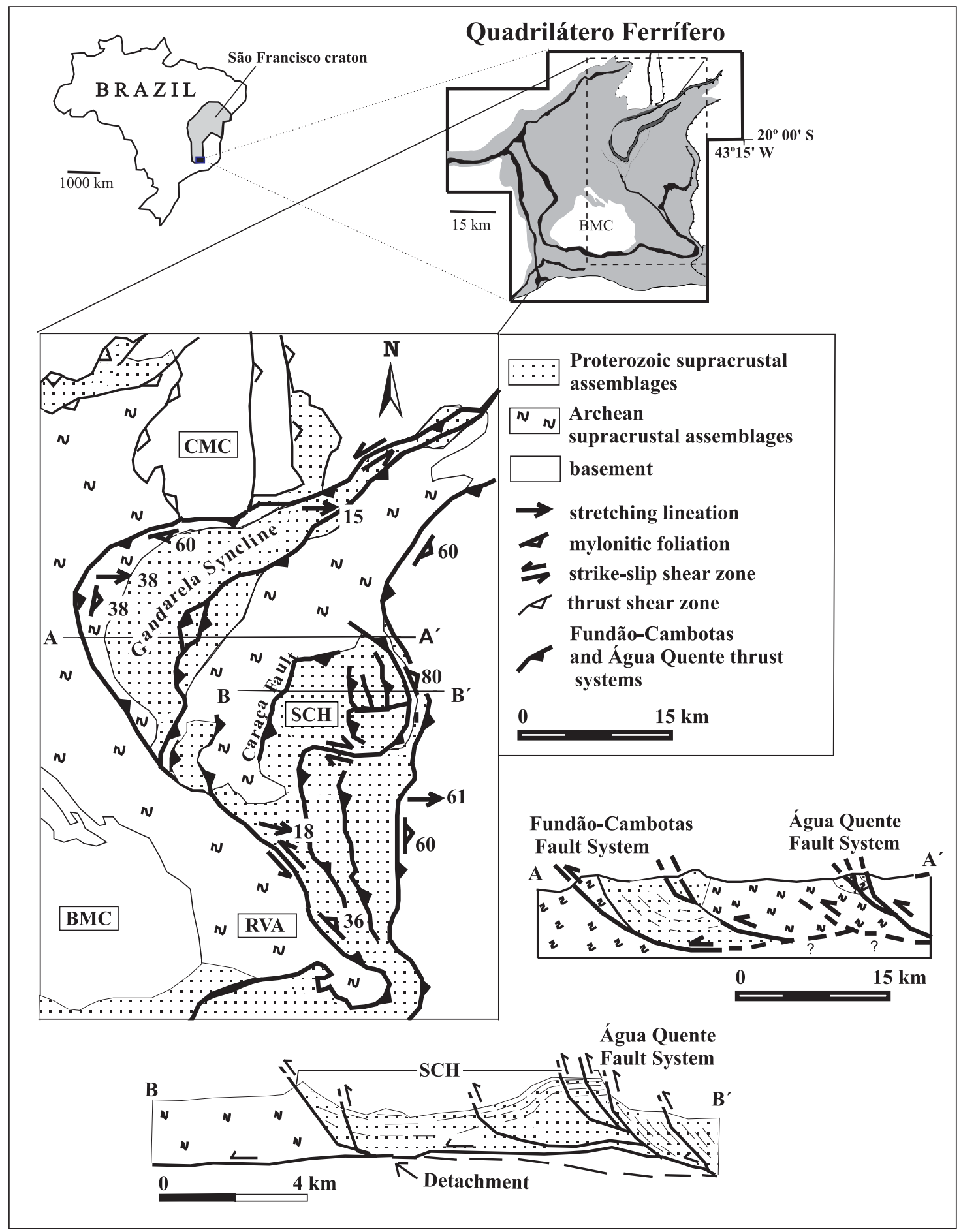

Fig. 1 - Location and simplified geologic-structural map of the eastern Quadrilátero Ferrífero with cross sections based on Endo and Fonseca (1992) and Ribeiro-Rodrigues (1992). CMC - Caetés Metamorphic Complex; BMC - Bação Metamorphic Complex; RVA Rio das Velhas Arch; SCH - Serra do Caraça structural high. 
In all the experiments the structural highs (the Caetés Metamorphic Complex and the Bação Metamorphic Complex/Rio das Velhas Arch) were represented by rigid triangular blocks placed in the north and south portions of the box, respectively (Fig. 2). The shape of these obstacles simulates the shape of the faults bounding the Fundão-Cambotas fault zones; on the south the border strikes $\mathrm{N} 45^{\circ} \mathrm{W}$ and on the north it trends $\mathrm{N} 60^{\circ} \mathrm{E}$. These different strikes produce distinct angles of convergence $(\alpha)$ between the deformation front and the basement highs, $\alpha=45^{\circ}$ in the south and $\alpha=30^{\circ}$ in the northern domain. The block representing the Caetés Metamorphic Complex high always stands out above the sand column $(3-5 \mathrm{~cm})$. In contrast, the block representing the Bação Metamorphic Complex/Rio das Velhas Arch is partially buried. This configuration allows the deformation front to advance over the southern high (except in model I and V) as indicated by the map pattern.

Experiments I to IV differ mainly by the modeling material used to test the supracrustal rock deformation. Model I (Fig. 2B), without any vertical anisotropy, is a "standard" experiment as it simulates the simplest conditions. In this model, a single pack of different colored dry sand layers overlying a plastic sheet simulates the supracrustal rocks. One thick $(0.5 \mathrm{~cm})$ mica layer and a sand bed interlayered with several thin mica laminations $(<0.1 \mathrm{~cm})$ add mechanical instabilities in experiments II and III ( Figs. 2C and D). In addition, in these experiments the base of the experimental box was covered by sandpaper to increase the coefficient of frictional sliding. In the foreland of experiment III, a wooden wedge was used to represent a pre-existing faulted structure at depth. A pack of pure sand overlying a $0.5 \mathrm{~cm}$ thick layer of silicone simulated a ductile basal detachment in experiment IV (Fig. 2E).

In experiments $\mathrm{V}$ and VI (Figs. $2 \mathrm{G}$ and $\mathrm{H}$ ) we used the same model set ups as in experiments I and IV, respectively, except that we introduced the Serra do Caraça structural high in the central-east portion of the deformation box. This high was simulated by a sub-cylindrical body that exceeded the sand pack in height and strength as described from the prototype (Ribeiro-Rodrigues 1992). The Serra do Caraça block, similar to the basement highs, was represented by a nearly vertical block in order to reproduce the situation in which horizontal to subhorizontal stretching lineations were produced at the obstacle lateral borders, in nature. In the models $\mathrm{V}$ and VI we analyzed what structures would form if an obstacle in the foreland would partly block the progressive displacement. The shortening began with the Serra do Caraça block acting as a rigid, fixed obstacle. With progressive deformation, the Serra do Caraça structural high began to move together with the deformation front.

\section{ANALOGUE MATERIALS}

Analogue modeling in sandboxes provides a tool for investigation of regional-scale deformation processes. The geometric similarity factor (Hubbert 1937) normally used in sandboxes is $10^{-5}$ or $10^{-6}$. Thus, we set up our models with $0.5 \times 10^{-5}$ such that the pack of analogue material whose thickness varies between 3 and $5 \mathrm{~cm}$, represents, respectively, 6 and $10 \mathrm{~km}$ in nature.

Many papers (e.g. Horsfield 1977, Vendeville et al. 1987, McClay and Ellis 1987 a,b) have described the usefulness of cohesionless dry sand, as an analogue material to simulate deformation in the upper brittle crust. The quartz sand deforms independent of strain rate and fails according to the Coulomb-Mohr criterion, with an angle of sliding friction close to $30^{\circ}$. The quartz sand used in our experiments is $0.2-0.3 \mathrm{~mm}$ in diameter and was artificially colored in order to permit the monitoring of the deformation.

The mechanical properties of shear zones in the Quadrilátero Ferrífero are not well known. Thus, we employed a variety of different materials to simulate distinct types of detachments: (i) a plastic sheet, representing a narrow fault zone at depth, (ii) sandpaper, simulating a low fluid pressure brittle shear zone, and (iii) a linear-viscous silicone (Newtonian) layer, modeling a high metamorphic ductile detachment which deforms by pervasive viscous flow. 


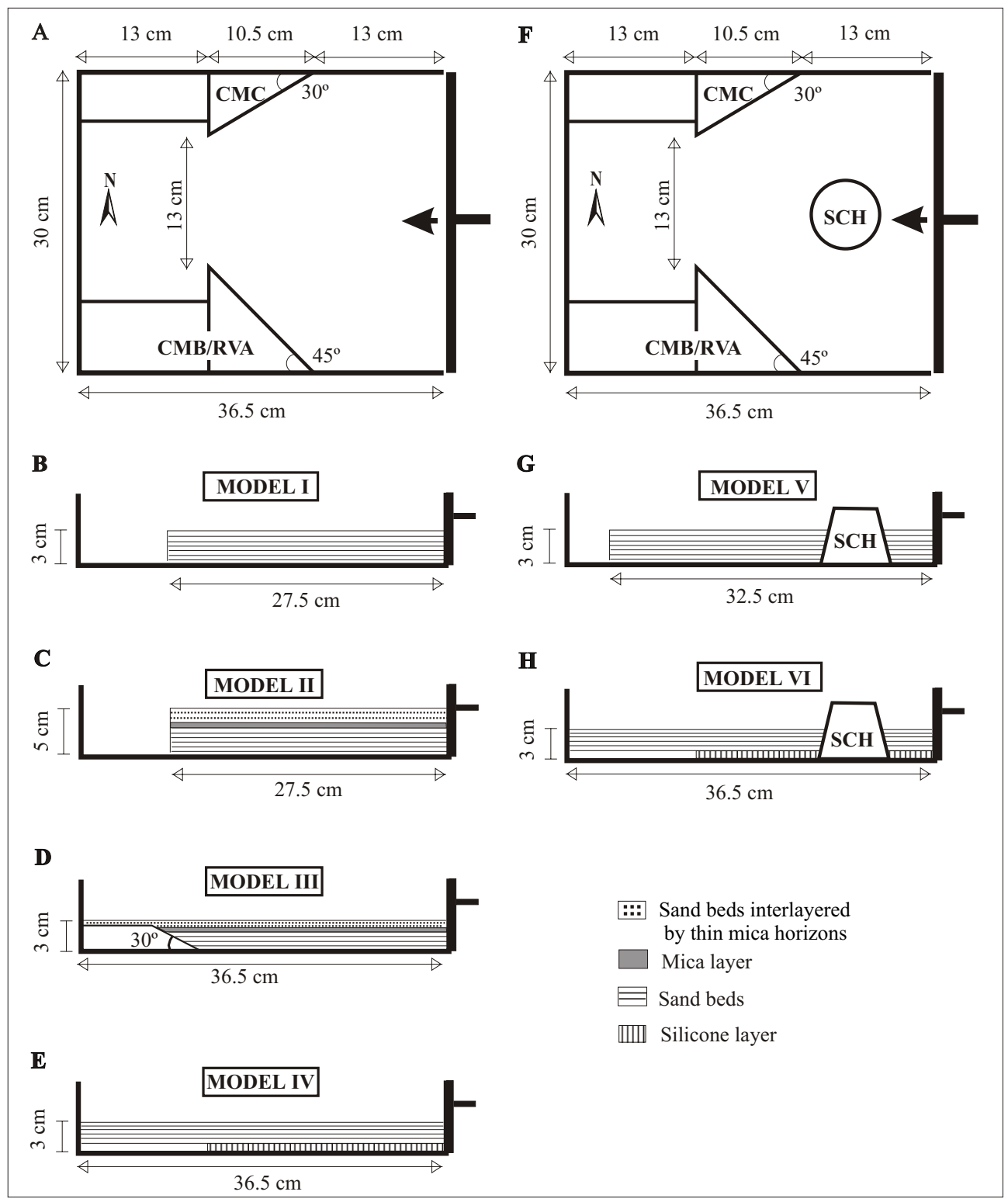

Fig. 2 - Schematic drawings of the experiments with respective boundary conditions. A - Plan-view of the experimental box used for models I to IV. B-, C-, D- and E - East-west sections through experiments I, II, III and IV, respectively. F - Plan-view of the experimental box used for models V and VI. G- and H - East-west sections through the experiments V and VI, respectively. Arrows indicate sense of displacement of the moving wall. SCH - Serra do Caraça structural high; CMC - Caetés Metamorphic Complex; BMC/RVA - Bação Metamorphic Complex/Rio das Velhas Arch.

To simulate the presence of a weak, non-linear material within the stratigraphic column (e.g. incompetent pelitic metamorphic rocks such as schists or phyllites) we included a $0.5 \mathrm{~cm}$ thick layer of mica crystals within the sand pack, to simulate a potential detachment level in quartzites. McClay (1990) demonstrates that the intercalation of mica horizons among sand layers induces intrastratal slid- 
ing in the sand pack. In previous experiments we demonstrated that a $0.5 \mathrm{~cm}$-thick layer of mica crystals in a brittle-deforming pack produces beddingparallel slip and plastic deformation during shortening through internal reorganization of the individual mica crystals leading to thickening of the layer (Gomes et al. 1999).

To maintain similarity between forces in the model and forces in the prototype (Hubbert 1937) we used the shortening rate of $2 \times 10^{-5} \mathrm{~m} / \mathrm{s}$ so that silicone putty (viscosity of $5 \times 10^{4} \mathrm{~Pa} \mathrm{~s}$ at room temperature) behaves with a properly scaled viscosity. Assuming a deformation velocity in nature of $3 \times 10^{-10} \mathrm{~m} / \mathrm{s}$ (Richard 1991), and densities of continental crust and silicone of $2800 \mathrm{~kg} \mathrm{~m}^{-3}$ and $1160 \mathrm{~kg} \mathrm{~m}^{-3}$, respectively, we obtained for the viscosity of the detachment, in nature, the value of $3.2 \times 10^{20} \mathrm{~Pa}$ s. This result is in the same order of magnitude as the viscosity of the lower crust $\left(10^{19}\right.$. $10^{22} \mathrm{~Pa} \mathrm{~s}$ ), suggesting that the use of silicone under the chosen shortening rate fulfills the dynamic similarity criteria.

\section{DESCRIPTION OF THE EXPERIMENTS}

Model I was subjected to a west-vergent total shortening of $22 \%(8 \mathrm{~cm})$. The deformation generated a thrust system in a forward-breaking sequence with initially straight traces in map-view. As the thrust wedge grew, the foreland leading edge became progressively more curved, and eventually developed a trapezoidal geometry (Fig. 3).

The vertical sections in experiment I (not shown here) revealed three thrusts in the central and northern domains, and the development of five thrusts in the southern domain. The greater shortening effects in the southern portion is interpreted as a consequence of the different angle of convergence $(\alpha)$ between the deformation front and both basement highs $\left(\alpha=45^{\circ}\right.$ in the southern and $\alpha=30^{\circ}$ in the northern domain).

In experiment II (Fig. 4) the total shortening of $26 \%(9.5 \mathrm{~cm})$ produced three thrusts in the $5 \mathrm{~cm}$ thick sand pack: one completely emergent thrust (fault 1), a second fault (fault 2) which emerges only in the northern domain, and fault 3 , a blind thrust with a ramp-flat geometry. The latter thrust has a staircase trajectory in cross section (Figs. 4C). In plan-view, two oblique ramps, which connect to the blind ramp-flat thrust (fault 3) at depth, border the basement highs (Fig. 4A).

In model III, $27 \%$ shortening $(10 \mathrm{~cm})$ generated a total of five emergent thrusts (Fig. 5). Oblique ramps border the structural highs and, with progressive deformation, local lateral ramps developed along fault 5 in the extreme west. The cross section of figure $5 \mathrm{~B}$ reveals the nucleation of a thrust fault with a staircase trajectory (fault 5). The fault trace of this staircase thrust has a lower ramp dip angle than that of the staircase thrust in model II, and it developed a second thrust ramp. This ramp which emerges in the distal foreland formed as a consequence of the presence of the wooden wedge (Fig. 5B).

In experiment IV, an oblique fault ramp bordering the Bação Metamorphic Complex/Rio das Velhas Arch was formed in the southern domain, after $5.5 \%(2 \mathrm{~cm})$ shortening. It was followed by the development of a frontal ramp in the foreland and of a new thrust in the hinterland nearly at the same time. After $16 \%(6 \mathrm{~cm})$ shortening, the northern segment of the first thrust appeared as a dextral oblique ramp, along the southern margin of the Caetés Metamorphic Complex high (Fig. 6A). After this stage, progressive shortening was accommodated exclusively by increasing slip along the previously formed faults. The variable deformation path from south to north, is interpreted as a consequence of the different angles of convergence of the deformation front relative to the basement-highs margins. Figure 6B shows the two thrust faults in the central domain of model IV, both with the silicone ascending along the fault plane. This explains the strong displacement of those thrusts and the low number of faults formed.

In experiment $\mathrm{V}$, the $16 \%(6 \mathrm{~cm})$ shortening produced three thrusts, all of them wrapping around the Serra do Caraça structural high (Fig. 7A). These thrusts developed between the Serra do Caraça structural high and the foreland basement highs, pro- 


\section{MODEL I}

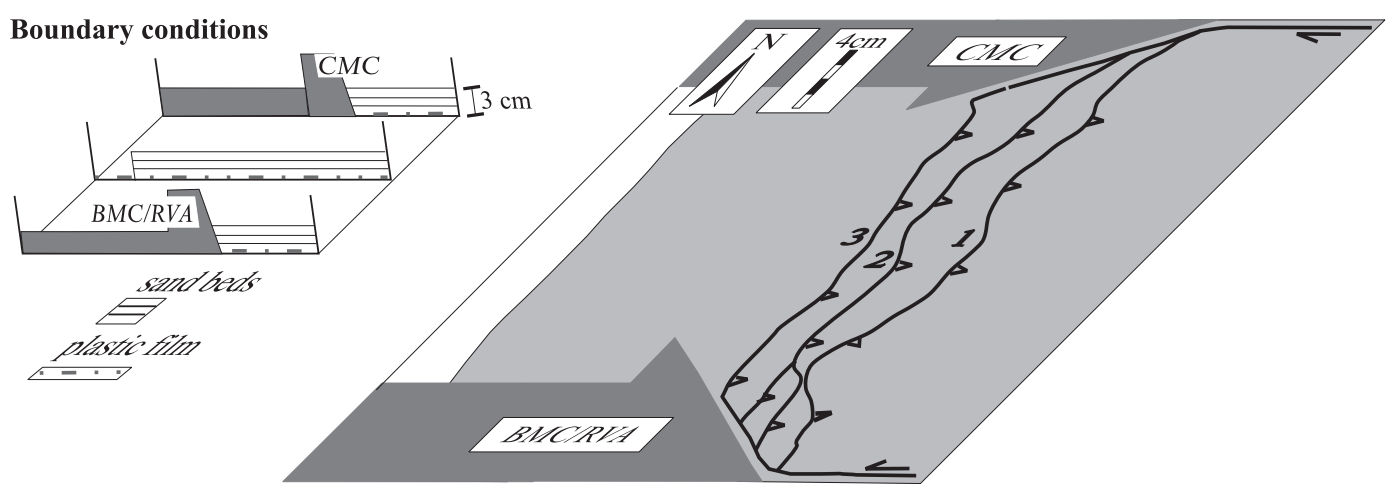

Fig. 3 - Plan-view line drawing of model I at the final stage of $22 \%(8 \mathrm{~cm})$ shortening showing the slightly rounded, trapezoidal thrust traces. Numbers 1 to 3 indicate the order of fault formation. CMC - Caetés Metamorphic Complex; BMC/RVA - Bação Metamorphic Complex/Rio das Velhas Arch.

\section{MODEL II}

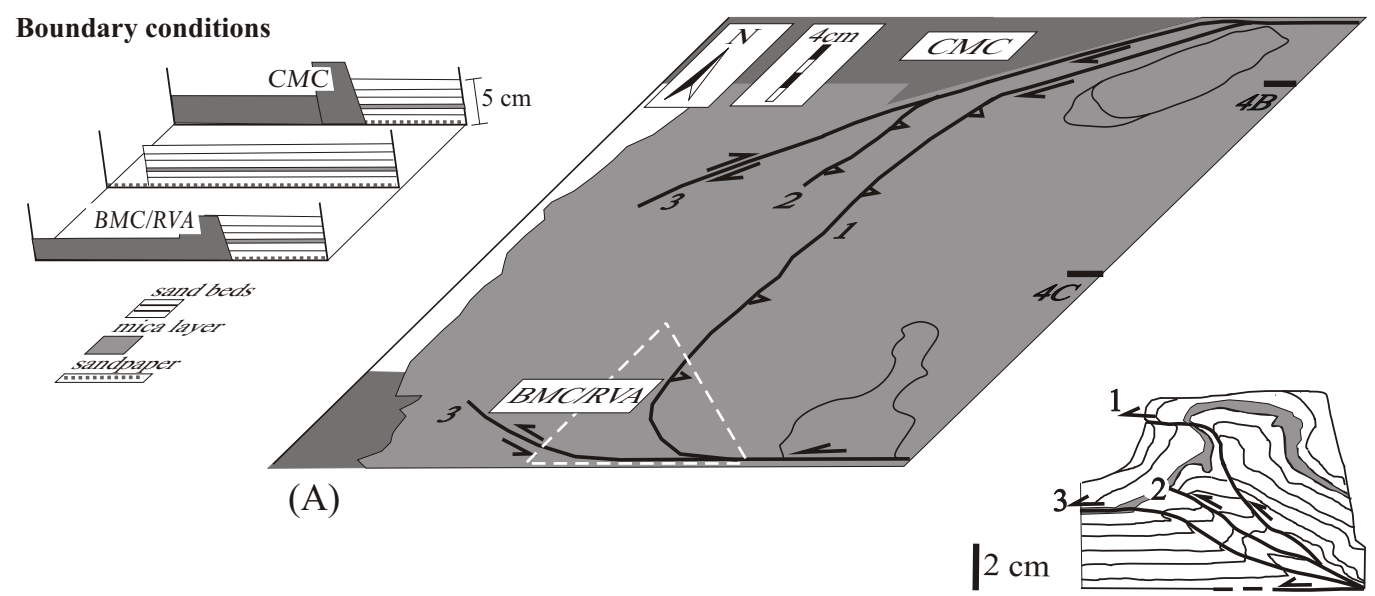

(B)

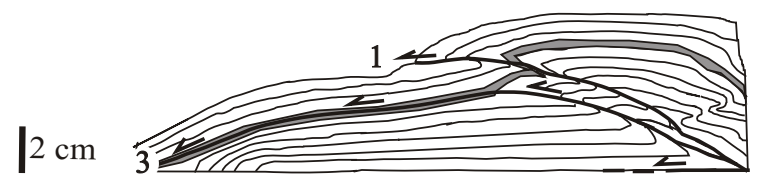

(C)

Fig. 4 - Plan-view and profile line drawings of model II, after $26 \%(9,5 \mathrm{~cm})$ shortening. A - A horizontal cut located at $2 \mathrm{~cm}$ from the top (at a height of $5 \mathrm{~cm}$ ) displaying the fault traces. The elliptical and irregular contour lines reveal the ascent of the analogue material which was particularly strong in the north, in the hinterland of the Caetés Metamorphic Complex. At the east margin of the plan-view line drawing the positions of the vertical profiles are indicated. B- and C - Vertical sections cut parallel to the tectonic transport direction showing the thrust faults at depth. Numbers 1 to 3 indicate the order of fault formation. CMC-Caetés Metamorphic Complex; BMC/RVA - Bação Metamorphic Complex/Rio das Velhas Arch. 


\section{MODEL III}

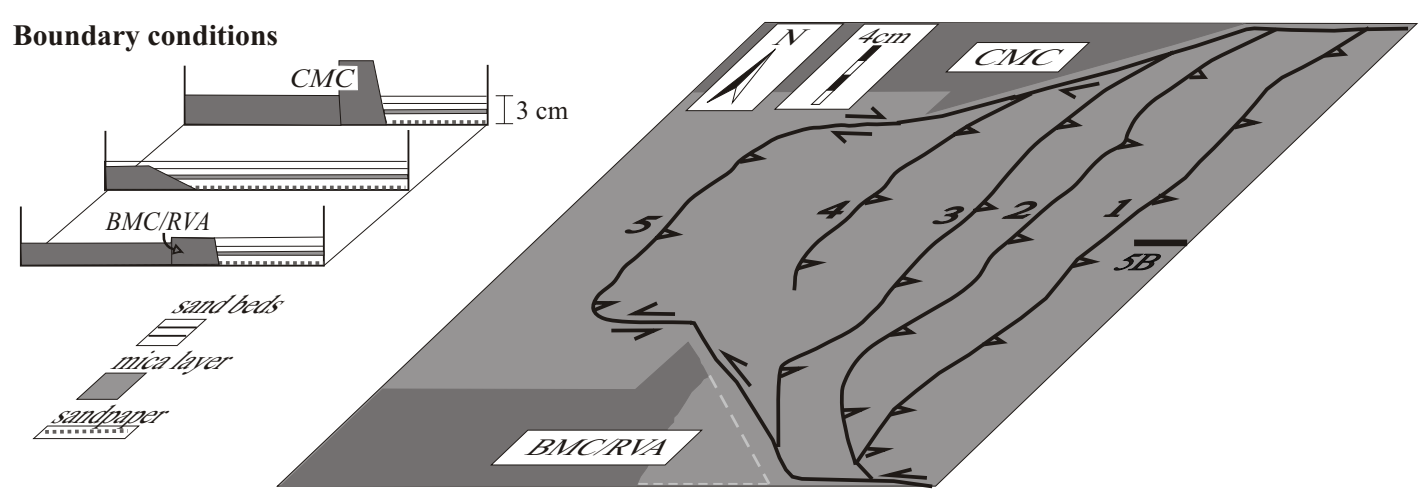

(A)

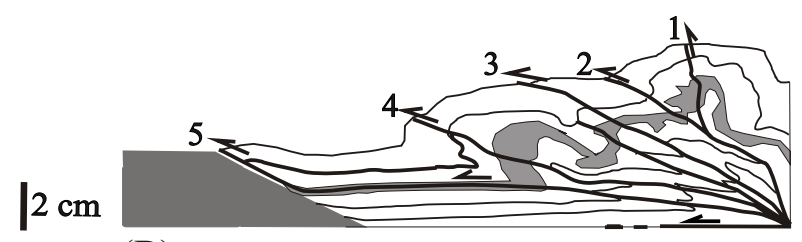

(B)

Fig. 5 - Plan-view and profile line drawings of model III, after $27 \%(10 \mathrm{~cm})$ shortening. A - Plan-view showing the traces of thrust faults, and of oblique and lateral ramps respectively along the structural highs and to their west side. B - Vertical section through the central domain displaying thrust 5 (the youngest fault) with a staircase trajectory. The dip angle of the older faults varies because of the mobile mica crystal layer. The plastic behavior of the mica layer (dashed, in the line drawing) is reflected by development of thickened and thinned domains. Numbers indicate the order of fault formation. CMC - Caetés Metamorphic Complex; BMC/RVA Bação Metamorphic Complex/Rio das Velhas Arch.

ducing slightly rectangular, convex-to-the-foreland horizontal traces. The curvature of the youngest thrust in the south (fault 3, in Figs. 7A and B) reflects the higher rate of convergence in this domain. The thrusts to the hinterland of the Serra do Caraça structural high experienced a strong clockwise rotation during progressive deformation (faults 1, 2 and 3, in Fig. 7C). When the Serra do Caraça structural high began to move with the deformation front, a new thrust formed in the foreland. Figure 7B shows in plan-view the curved geometry of this new thrust (the Fundão-Cambotas Fault System's leading edge) after additional $2 \mathrm{~cm}$ shortening (21.5\% of total shortening). The profiles cut in experiment $\mathrm{V}$ (Figs. 7C and D) show the Fundão-Cambotas Fault System as a west-verging ramp thrust linked at depth to a basal detachment beneath the Serra do Caraça structural high.
In experiment VI (Fig. 8), at initial stages of shortening the same deformational process as occurred in model $\mathrm{V}$ was observed. Thus, the leading edge of the Fundão-Cambotas Fault System only developed when the Serra do Caraça structural high began to move, after $16 \%(6 \mathrm{~cm})$ shortening. Up to this stage, a single thrust had formed contouring the Serra do Caraça structural high. This thrust was rotated to nearly vertical in the Serra do Caraça structural high hinterland (Fig. 8D). After 30\% shortening $(11 \mathrm{~cm})$, two younger thrusts with curved geometries (faults 2 and 3, Fig. 8B) emerged in the foreland. The vertical sections (Figs. 8C, D and E) reveal thickening of the silicone layer and a strong displacement along the youngest fault 3 as well as along the backthrust of fault 2, north and south of the Serra do Caraça structural high. In contrast, a relatively small slip was observed along thrust 2 and 


\section{MODEL IV}

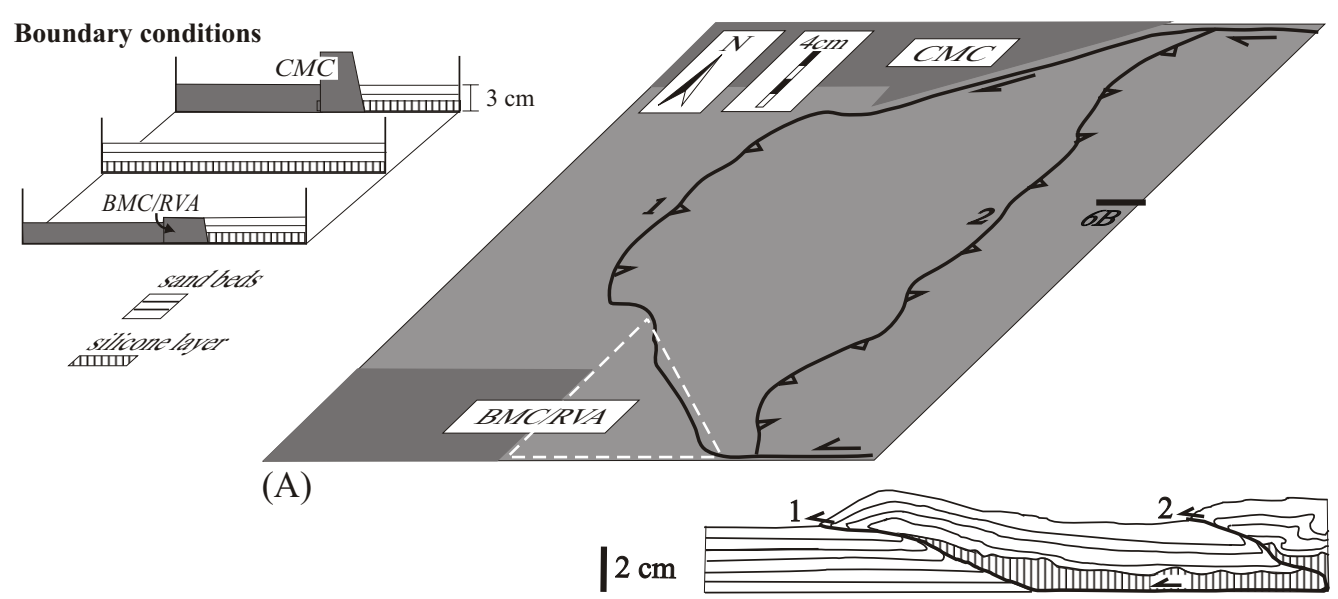

(B)

Fig. 6 - Plan-view and profile line drawings of model IV, with a silicone layer simulating a ductile basal detachment. A - The experiment in plan-view after 16\% (6 cm) shortening showing the thrust trace of the Fundão-Cambotas Fault System in the foreland (fault 1), and the Água Quente Fault System in the hinterland (fault 2). B - Vertical section in the central portion of the experiment exhibiting the thrust faults in profile view. Numbers indicate the order of fault formation. CMC - Caetés Metamorphic Complex; BMC/RVA - Bação Metamorphic Complex/Rio das Velhas Arch.

its backthrust, in the immediate foreland of the Serra do Caraça structural high. This difference is a consequence of the viscous behavior of silicone, which allows material transfer out of regions submitted to the highest compressive stress (the Serra do Caraça structural high foreland) into those of lower stress (the northern and southern domains).

\section{DISCUSSION}

\section{Thrusts IN MAP-VIEW}

Margin-controlled salients were simulated in sandboxes by Marshak (1988), Marshak et al. (1992) and Macedo and Marshak (1999) and their geometry, in plan-view, was related to the length of a backstop or to the space between obstacles. The greater the distance between obstacles, the smaller the amplitude of the salient and the stronger its tendency to form a rectangular curved trace. According to Marshak and Wilkerson (1992), the increase in the sand-layer thickness modifies this relationship since a greater thickness causes the thrust (whose dip angle of $30^{\circ}$ does not vary) to propagate further into the confined foreland. The present experiments demonstrate how, in a margin-controlled fold-thrust belt, different structural situations may produce different salient geometries in map-view.

A comparison between the curvature of the real Fundão-Cambotas Fault System with the respective analogue models shows that only experiments I and II (Fig. 9) are totally different from the natural prototype. The "standard" experiment, model I, demonstrates that the $3 \mathrm{~cm}$ thick sand pack (the $6 \mathrm{~km}$-thick supracrustal rocks, in nature) does not reproduce the original. The obstacles impeded the progressive movement. The $5 \mathrm{~cm}$-thick, mica bed interlayered, sand pack of model II presented a similar result.

Both experiments in which silicone was used to simulate the basal detachment (models IV and VI) produced, in the map-view, a closed curvature of the leading thrust. This curvature was produced by the fast degree of the propagation rate in the silicone. As 


\section{MODEL V}

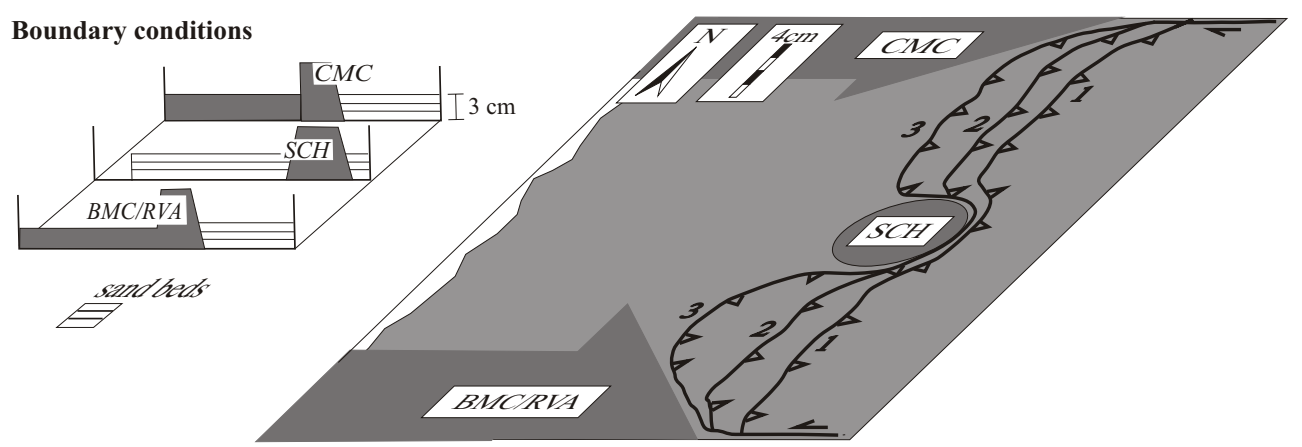

(A)

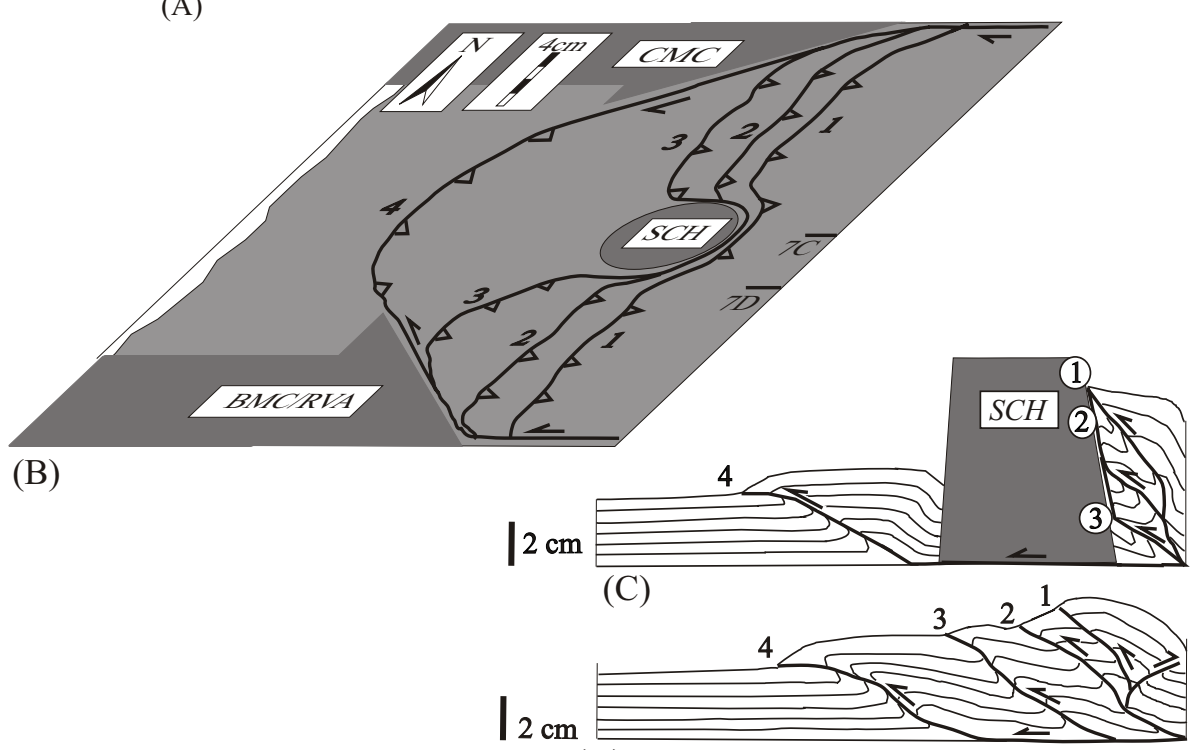

(D)

Fig. 7 - Plan-view and profile line drawings of model V which simulates the Serra do Caraça structural high between the Caetés Metamorphic Complex and the Bação Metamorphic Complex/Rio das Velhas Arch structural highs. A - The thrust traces in plan-view after 16\% (6 cm) shortening with the Serra do Caraça structural high acting as a fixed obstacle. B - The same thrusts after $21.5 \%$ shortening with the Serra do Caraça structural high dislocated $2 \mathrm{~cm}$ into the foreland. In B, the youngest fault (fault 4) represents the frontal ramp of the leading edge of the Fundão-Cambotas Fault System, and faults 1, 2 and 3 simulate the Água Quente Fault System. At the eastern margin, the positions of the vertical profiles are indicated. C - and D- Vertical sections showing the thrusts in profile. Note in section C, the strongly rotated thrusts of the Água Quente Fault System in the hinterland of the Serra do Caraça structural high. Numbers 1 to 4 indicate the order of fault formation. SCH - Serra do Caraça structural high; CMC - Caetés Metamorphic Complex; BMC/RVA - Bação Metamorphic Complex/Rio das Velhas Arch.

the space between lateral obstacles decreases to the foreland the new thrust fault emerges with a strong parabolic geometry.

The leading edge of the Fundão-Cambotas Fault System salient of models III and V, resulted from their special structural configuration. In model
III, a thrust fault with a staircase trajectory developed as a consequence of the presence of a mica layer and of a wooden wedge in the foreland. The parabolic curvature of thrust 4 in model $\mathrm{V}$, without any weak detachment, is related to the presence of the Serra do Caraça structural high. With progres- 


\section{MODEL VI}

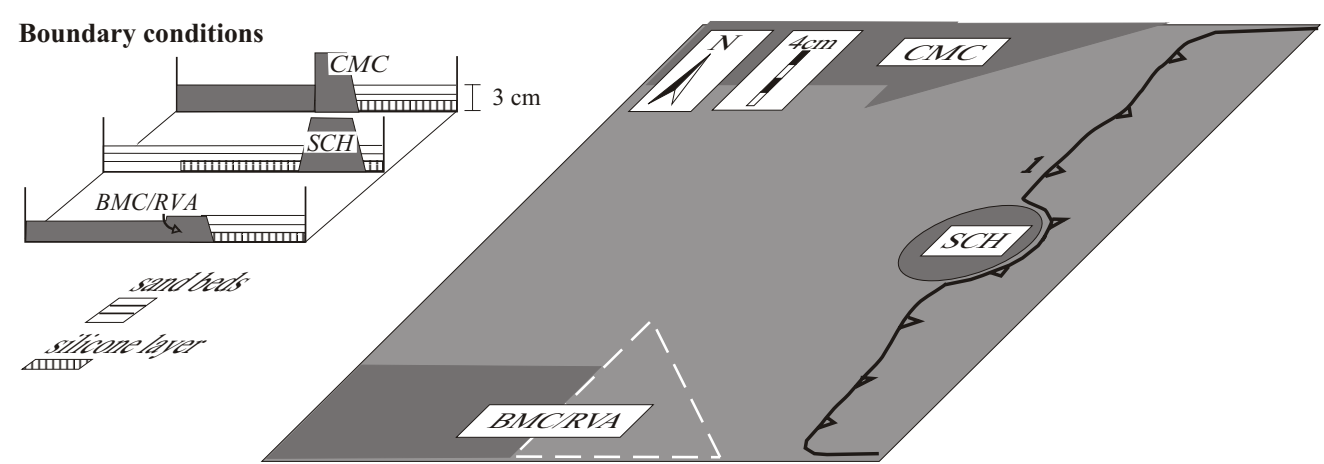

(A)

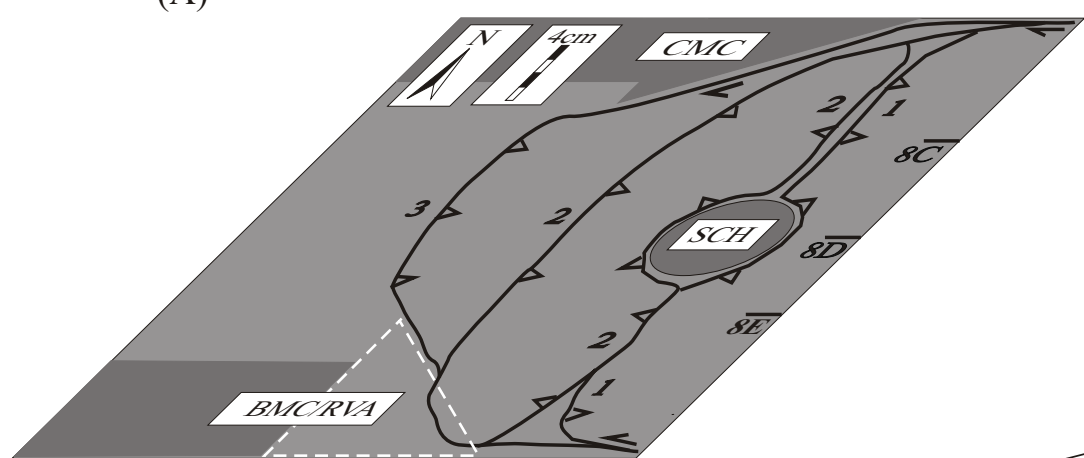

(B)

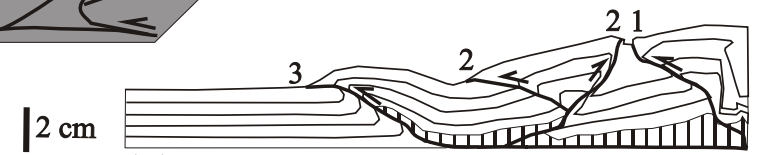

(C)

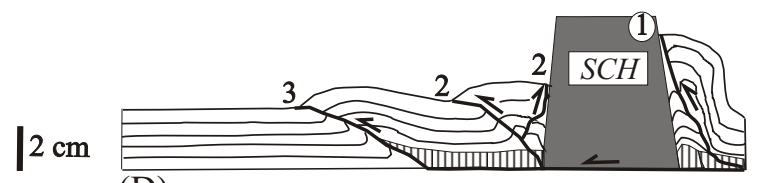

(D)

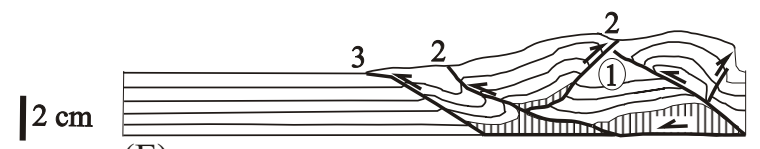

(E)

Fig. 8 - Plan-view and profile line drawings of model VI which simulates the Serra do Caraça structural high between two basement highs; the basal detachment is represented by a silicone layer. A and B - The model after $16 \%(6 \mathrm{~cm})$ shortening with the Serra do Caraça structural high fixed, and after $30 \%(11 \mathrm{~cm})$ shortening, respectively. In B, the position of the vertical sections are represented. C, D and E - Vertical sections showing thrusts and backthrusts. In D, note that fault 1 (representing the Água Quente Fault System) to the east of the Serra do Caraça structural high, appears nearly vertical. Numbers indicate the order of fault formation. SCH - Serra do Caraça structural high; CMC - Caetés Metamorphic Complex; BMC/RVA - Bação Metamorphic Complex/Rio das Velhas Arch. 


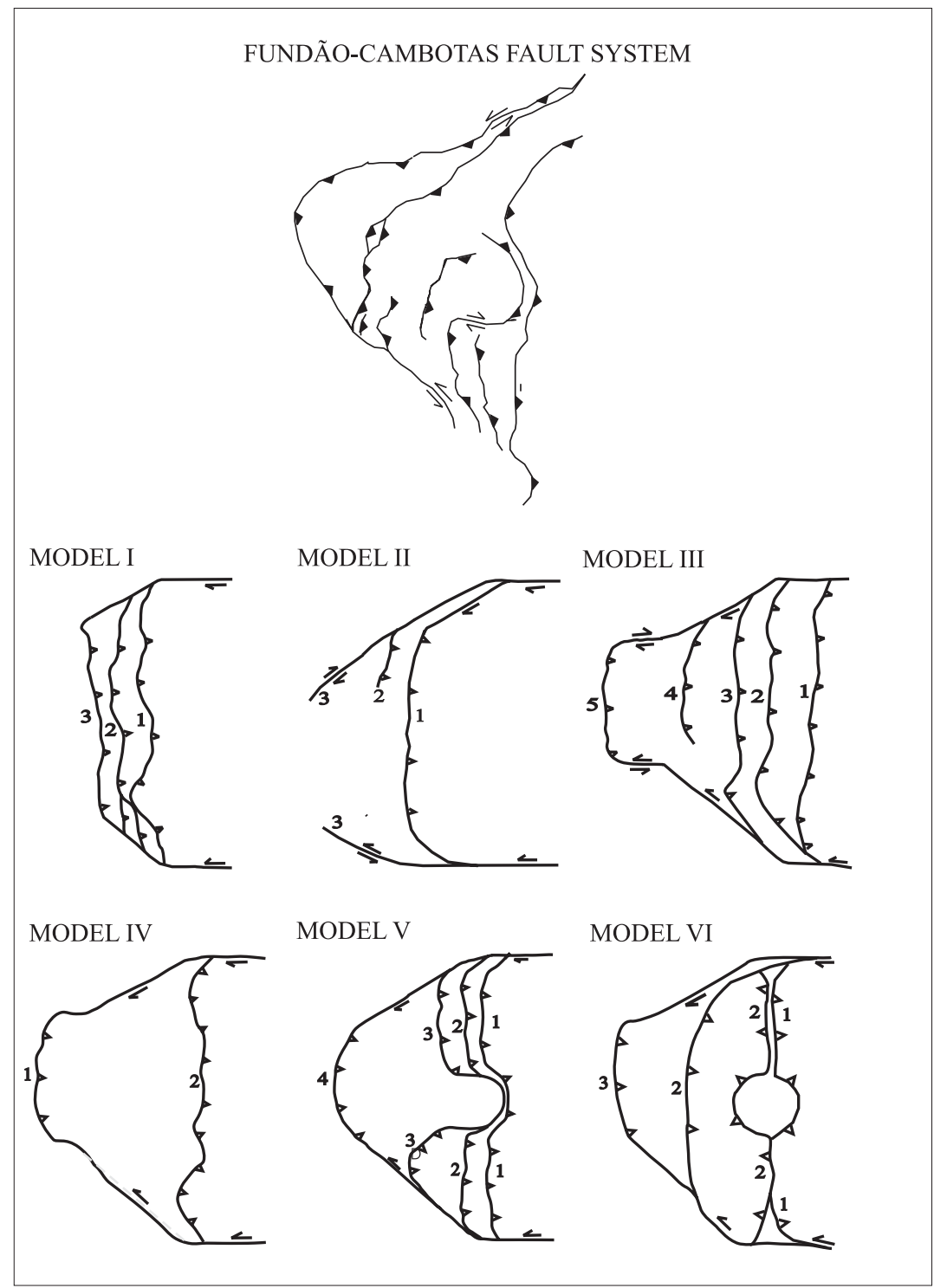

Fig. 9 - Simplified structural map of the Fundão-Cambotas Fault System and the results of sandbox models I to VI.

sive deformation, the Serra do Caraça structural high was dislocated together with the previously formed sand pile such that the whole deformation front assumed the role of a new backstop, laterally confined between the two obstacles. The shortening produced a new, strong curved thrust trace in map-view (fault 4 , in figure 7B) which curvature was particularly pronounced in consequence of the restricted space between the lateral obstacles in the foreland.

\section{Thrusts AT DEPTH}

Formation of thrusts with a ramp-flat geometry in models II and III depends on the presence of the intermediate mica crystal layer and on the presence of high shear strength along the basal surface. Resistance on the basal sliding surface blocked the forward-breaking faulting process. As deformation proceeds, the shortening was transferred to the in- 
terlayered low friction strata producing ramp and flat segments, in competent and incompetent layers respectively. Gomes et al. (1999) describe the generation of staircase-faults in experiments, and concluded that they only form when a high sliding coefficient contrast exists between basal and intermediate detachments. In experiments without a weak interlayered bed, but with a high shear strength along the basal surface, the shortening was accommodated by the formation of an anticlinal stack (Huiqi et al. 1992, Gomes and Ferreira 2000). Similar staircase thrusts were produced experimentally by Perotti et al. (1999) in a sand pack interlayered with beds of glass microbeads, with a frictional angle of $21^{\circ}-22^{\circ}$.

The models with silicone simulating the basal detachment (experiments IV and VI) produced, at depth, quite different structural configurations compared to those with a pure sand pack or a sand-mica pack. In experiment IV the thrust system developed with a break-back sequence, in that the youngest thrust formed in the hanging wall of the older one. No backthrust formed in this model. In model VI, the fault system in the foreland of the Serra do Caraça structural high developed a forwardbreaking sequence with simultaneous formation of forethrusts and backthrusts. The development of forethrusts and backthrusts in the brittle overburden occurred when the ductile substrate was constrained by rigid buttresses. While the viscous silicone accommodates the shortening by plastic thickening, the brittle sand produces fractures, developing forethrusts and backthrusts. The break-back sequence, in model IV, resulted from the relatively longer distance between buttresses with the same shortening as compared with experiment VI. The broad deformation domain causes a minor thickening of both the silicone layer and the overlying sand pack. In consequence, the low degree of shortening was accommodated by a second forethrust in the hinterland, instead of the backthrust in model VI.

\section{Oblique RAmps In EXPERIMENT AND NATURE}

An additional effect of the deformation in a margin-controlled structural domain appears par- ticularly clear in the horizontal section of experiment II, where the weak stratigraphic layer is represented by a mica crystal bed and the whole sand pack overlies sandpaper. The strong ascent of the analogue material at the northern oblique ramp (Fig. 4B) suggests a pure shear dominated transpression. This deformation was the result of strike-slip movement combined with clockwise rotation of thrusts when movement was partly blocked in front of the Caetés Metamorphic Complex. In the viscous, high mobile silicone models (models IV and VI) simple shear wrenching prevails at the oblique ramps, and in the "standard" model I only pure shearing occurs. A full spectrum of the deformation between contraction and strike-slip may occur at oblique ramps depending on the detachment rheology (from pure shear dominated transpression to wrench dominated transpression, according to Fossen et al. 1994) but must be tested in a more complete modeling program. At the northern oblique ramp of the real Fundão-Cambotas Fault System two factors indicate transpression: the sub-horizontal stretching lineations on the southern border of the Caetés Metamorphic Complex and the Gandarela Syncline geometry, in map-view. The syncline's outcrop is wider in the southwest than it is in the northeast (Fig. 1), suggesting confinement near the Caetés Metamorphic Complex.

\section{CONCLUSIONS}

The experiments illustrate how variation in the rheology of detachments and pre-existing structures could influence the margin-controlled curvature of thrusts, in profile and map-view. Thrust salients due to interaction with lateral obstacles produced a trapezoidal geometry in a pure, $3 \mathrm{~cm}$-thick, sand pack and a high parabolic thrust trace above a basal ductile detachment. In the first case, the obstacles impede progressive movement of thrust sheets, whereas the fast degree of the propagation rate in a silicone layer caused the development of oblique ramps at the lateral obstacles and frontal ramps in the distal foreland. An intermediate ductile detachment produces a high thrust trace curvature in map-view, 
when a high sliding coefficient contrast exists between basal and intermediate detachments. A high parabolic salient is also produced by the action of an indenter in the hinterland of a fold-thrust belt.

The correlation with a natural example aims to provide new ideas to the severely overprinted and badly exposed structural assemblage of the FundãoCambotas Fault System, in the Quadrilátero Ferrífero. Our physical models illustrate how the highly parabolic salient in the Fundão-Cambotas Fault System could have formed. We suggest a combination of different factors, i.e. the interaction of a thrust system with obstacles in the foreland (i) in the presence of a ductile detachment, or (ii) in the presence of pre-existing structures.

\section{ACKNOWLEDGMENTS}

We thank João Hippertt and Stephen Marshak for constructive critical reading of the manuscript. The modeling was supported by FAPEMIG and CNPq (grants CRA 2637/97 and 300487/89, respectively).

\section{RESUMO}

Em presente trabalho são desenvolvidos experimentos, em escala, em caixas de areia, para a simulação de saliências pelo processo de propagação de sistemas compressivos ao longo de margens irregulares. Estes modelos visam analisar a configuração estrutural do Sistema de Cisalhamento Fundão-Cambotas, no cinturão de dobras e falhas proterozóico, do domínio leste do Quadrilátero Ferrífero, sudeste do Craton São Francisco. Investigaram-se as possíveis causas para a formação de curvaturas, em planta, mantendo-se constantes os parâmetros, espessura do pacote de areia e distância entre obstáculos no antepaís. Os experimentos demonstram que a formação de saliências fortemente curvas ocorre ao longo de margens irregulares, na presença de um descolamento basal dúctil ou pela ação de estruturas pré-existentes. Assim, relaciona-se a geometria convexa do Sistema de Cisalhamento FundãoCambotas, ladeado, a norte e a sul, por altos estruturais do embasamento arqueano, vergente para oeste e que desloca estruturas transamazônicas, mais antigas, parcialmente à ação de obstáculos laterais.

Palavras-chave: modelagem física, saliências, deforma- ção rúptil, deformação dúctil, Quadrilátero Ferrífero.

\section{REFERENCES}

Alkmim FF AND MarshaK S. 1998. Transamazonian Orogeny in the Southern São Francisco Craton Region, Minas Gerais, Brazil: evidence for Paleoproterozoic collisin and collapse in the Quadrilátero Ferrífero. Precambr Res 90: 29-58.

Carey SW. 1955. The orocline concept in geotectonics. Paper Proceedings Royal Society Tasmania 89: 255-289.

DORR JVN. 1969. Physiographic, stratigraphic and structural development of the Quadrilátero Ferrífero, Brazil. USGS Prof Paper 641 (A).

Endo I ANd Fonseca MA. 1992. Sistema de Cisalhamento Fundão - Cambotas no Quadrilátero Ferrífero - MG: geometria e cinemática. In: SimPósio de Geologia de Minas Gerais, 6., Ouro Preto, Anais, p. 29-31.

Fossen H, Tikoff B And Teyssier C. 1994. Strain modeling of transpressional and transtensional deformation. N Geol Tidsskrift 74: 134-145.

Gomes CJS and Ferreira JE. 2000. Geometry and Kinematics of Experimental Antiformal Stacks. An Acad Bras Cienc 72: 195-217.

Gomes CJS, Ferreira JE and Pereira Filho M. 1999. Modelos físicos de falhas de empurrão com trajetória em degrau. Rev Bras Geocienc 29: 539-548.

HoRsFIELD WT. 1977. An experimental approach to basement controlled faulting. Geol Mijn 56: 363-370.

HubBert MK. 1937. Theory of scale models as applied to the study of geologic structures. Geol Soc Am Bull 48: 1459-1520.

Huiqi L, McClay KR and Powell D. 1992. Physical models of thrust wedges. In: McClay KR (Ed.). Thrust Tectonics, London: Chapman Hall, p. 71-81.

Macedo JM. 1997. Models of continental fold-thrust belt salients. Unpublished $\mathrm{PhD}$. thesis, UrbanaChampaign, University of Illinois, 295 pp.

Macedo JM and MarshaK S. 1999. Controls on the geometry of fold-thrust belt salients. Geol Soc Am Bull 111: 1808-1822.

MarshaK S. 1988. Kinematics of orocline and arc formation in thin-skinned orogens. Tectonics 7: 73-86.

MarshaK S AND WiLKERSON MS. 1992. Effect of over- 
burden thickness on thrust belt geometry and development. Tectonics 11: 560-566.

Marshak S, Wilkerson MS and Hsui AT. 1992. Generation of curved fold-thrust belts: Insight from simple physical and analytical models. In: MCCLAY KR (Ed.). Thrust Tectonics, London: Chapman Hall, p. 83-92.

McClay KR. 1990. Extensional fault systems in sedimentary basins: a review of analogue model studies. Marine and Petroleum Geol 7: 206-233.

McClay KR AND Ellis PG. 1987a. Analogue models of extensional fault geometries. In: CowARD MP ET AL. (Eds.). Continental Extensional Tectonics. Geol Soc London Spec Pub 28, p. 109-125.

McClay KR AND Ellis PG. 1987b. Geometries of extensional fault systems developed in model experiments. Geology 15: 341-344.
Perotti CR, Ravaglia A And Turrini C. 1999. Geometry and kinematics of staircase thrusts in sandbox analogue models. In: Thrust Tectonics ConferENCE. London. Extended abstracts, p. 289-292.

Ribeiro-Rodrigues LC. 1992. O contexto geológicoestrutural do Parque Natural do Caraça e Adjacências, Quadrilátero Ferrífero, Minas Gerais. Unpublished M.S. thesis, Universidade de Brasília. 133pp.

RichARD P. 1991. Experiments on faulting in a twolayer cover sequence overlying a reactivated basement fault with oblique-slip. J Struct Geol 13: 459-469.

Vendeville B, CobBold PR, Davy P, Brun JP AND Choukroune P. 1987. Physical models of extensional tectonics at various scales. In: COWARD MP ET AL. (Eds). Continental Extensional Tectonics. London. Geol Soc London Spec Publ 28, p. 95-107. 